\title{
Evaluation of Risk Factors Associated with Stroke Recurrence in Patients with Minor Ischemic Stroke
}

\author{
Minör İskemik İnmeli Hastalarda İnme Rekürrensi ile İlişkili Risk Faktörlerinin \\ Değerlendirilmesi
}

\author{
(1) Yasemin Dinç11, () Emel Oğuz Akarsu1, () Bahattin Hakyemez², (1) Mustafa Bakar ${ }^{1}$ \\ ${ }^{1}$ Bursa Uludag University Faculty of Medicine, Department of Neurology, Bursa, Turkey \\ Bursa Uludag University Faculty of Medicine, Department of Radiology, Bursa, Turkey
}

\begin{abstract}
Objective: Recurrent ischemic stroke (RIS) is a major threat to patients with IS. The risk of RIS in patients with minor IS (MIS) is 10-13\% in the first 3 months. Despite the advanced examination and treatment of the patients, RIS is still common. It is important to know which risk factors cause RIS in order to take some precautions. The aim of this study is to determine the risky group by determining the demographic, clinical and radiological features associated with RIS in patients with MIS.

Materials and Methods: We included 310 patients diagnosed as having acute IS (AIS) by Bursa Uludag University Faculty of Medicine Department of Neurology between 01.01.2019 and 01.01.2020, retrospectively.

Results: When clinical, radiological and dermogrophic features were analyzed between patients with and without RIS, there were statistically significant differences between groups in terms of the presence of coronary artery disease (CAD), atherosclerotic vascular disease, anterior circulation stroke, craniocervical atherosclerotic stenosis, atherosclerotic stenosis in the anterior circulation, atherosclerotic stenosis of the symptomatic internal carotid artery (ICA), atherosclerotic stenosis in the asymptomatic ICA and performing carotid artery stenting. When significant variables were analyzed by using binary logistic regression in patients with MIS, it was found that the most significant variables were CAD and asymptomatic ICA stenosis.

Conclusion: In our study, the risk factors associated with RIS in patients with MIS were the presence of CAD and asymptomatic ICA stenosis. Atherosclerosis is a systemic disease and therefore craniocervical atherosclerotic stenosis may be multiple. Angiographic evidence has also revealed ethnic and racial differences in patients with AIS. For this reason, more precise information can be obtained with prospective studies to be conducted in our own population.
\end{abstract}

Keywords: Minor stroke, carotid artery disease, stroke recurrence

$\ddot{O} \mathbf{z}$

Amaç: İskemik inme rekürrensi (İ̈R), İI hastanın karşı karşıya olduğu büyük bir tehdittir. Minör III’si (Mİ̇) olan hastalarda İIR riski ilk 3 ayda \%10-13’tür. Hastaların ileri tetkik ve tedavisine rağmen, İIR hala sıktır. Hangi risk faktörlerinin İ̇R'ye sebep olduğunu bilmek bazı önlemlerin alınması açısından önemlidir. Bu çalışmanın amacı MİI'li hastalarda İIR ile ilişkili dermografik, klinik ve radyolojik özelliklerin saptanarak riskli grubun belirlenmesidir.

Gereç ve Yöntem: Bu çalışmaya 01.01.2019-01.01.2020 tarihleri arasında Bursa Uludağ Üniversitesi Tıp Fakültesi Nöroloji Anabilim Dalı tarafından akut İ̇ (AIII) tanis1 konulan 310 hasta retrospektif olarak taranarak dahil edildi.

Bulgular: İR'si olan ve olmayan hastalarda klinik, radyolojik ve demografik özellikler analiz edildiğinde; koroner arter hastalığı (KAH) varlığı, aterosklerotik damar hastalığı, anterior sirkülasyon inmesi, kraniyoservikal aterosklerotik stenoz, anterior sirkülasyonda aterosklerotik stenoz, semptomatik internal karotid arterde aterosklerotik stenoz, asemptomatik internal karotis arterde (İCA) aterosklerotik stenoz ve karotis arter stentleme işleminin yapılması açısından istatistiksel olarak anlamlı farklılıklar saptandı. Mİ̀’li hastalarda anlamlı değişkenler binary logistik regresyon ile analiz edildiğinde en anlamlı değişkenlerin KAH ve asemptomatik İCA stenozu olduğu saptandı.

Sonuç: Çalışmamızda Mİ̇'li hastalarda İIR ile en ilişkili risk faktörleri KAH varlı̆̆ı ve asemptomatik İCA stenozu olarak saptanmıştır. Ateroskleroz sistemik bir hastalıktır ve bu sebeble kraniyoservikal aterosklerotik stenoz multipl olabilir. Anjiyografik kanıtlar Aİ́’li hastalarda etnik ve ırksal farklılıkları da ortaya koymuştur. Bu sebeple kendi popülasyonumuzda yapılacak prospektif çalışmalarla daha kesin bilgilere ulaşılabilir.

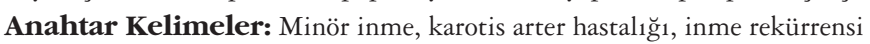

Yazışma Adresi/Address for Correspondence: Yasemin Dinç MD, Bursa Uludag University Faculty of Medicine, Department of Neurology, Bursa, Turkey Phone: +90 5301790512 E-mail: yaseminden87@ hotmail.com ORCID: orcid.org/0000-0003-0342-5939

Received/Gelis Tarihi: 10.03.2021 Accepted/Kabul Tarihi: 10.12 .2021

${ }^{\circ}$ Copyright 2022 by Turkish Neurological Society

Turkish Journal of Neurology published by Galenos Publishing House. 


\section{Introduction}

Recurrent ischemic stroke (RIS) is a major threat to the patients with IS. RIS account for $25 \%$ of the total number of IS that occur each year (1). The risk of RIS in patients with minor IS (MIS) is $10-13 \%$ in the first 3 months, and approximately half of the events occur in the first 2 days (2,3). MIS is defined as IS with a "National Institutes of Health Stroke Scale" (NIHSS) score below 5 (4). In population-based studies, approximately two-thirds of patients with IS have mild deficits. Comprehensive examination and treatment in patients with MIS lead to better clinical outcome, less cost, and less neurological deficit $(5,6)$.

What is done in routine practice to prevent RIS is to determine the etiology of stroke, to initiate the appropriate pharmacological agent, and to provide revascularization of the stenotic vessel (carotid endarterectomy or carotid stenting procedure) in patients with craniocervical atherosclerotic stenosis $(7,8)$. Despite the advanced examination and treatment of the patients, RIS is still common (9,10). Knowing which risk factors cause RIS is important for taking some precautions. The aim of this study is to determine the risk group by determining the demographic, clinical and radiological features associated with RIS in patients with MIS.

\section{Materials and Methods}

Between 01.01.2019 and 01.01.2020, 310 patients diagnosed as having acute IS (AIS) in the Neurology Department of Uludag University Faculty of Medicine were retrospectively scanned and included in this study. Patients with MIS were divided into 2 groups as those with and without RIS, and clinical dermographic and radiological features of both groups were compared. Approval for the study was obtained from the Clinical Research Ethics Committee of Bursa Uludag University Faculty of Medicine with the letter dated 03.03.2021 and numbered 2021-5/13. Since it was a retrospective study, patient consent was not required.

Inclusion criteria for the study were admission to the Emergency Department of Bursa Uludag University Medical Faculty within 24 hours following the focal neurological deficit, being diagnosed as having AIS after neurological examination and neuroimaging, having a NIHSS score of less than 5, being followed up in the neurology clinic, having a determined etiology of stroke, undergoing examination with computerized tomography (CT) angiography, having regular follow-ups in the neurology stroke outpatient clinic for 3 months after discharge, and having a determined clinical outcome. Exclusion criteria in the study were; high urea and creatinine levels, failure to perform CT angiography, failure to complete the necessary tests to clarify the etiology of stroke, leaving regular follow up in our neurology outpatient clinic, and having a NIHSS score higher than 5 .

All patients were examined by a neurologist and neurology assistants in the emergency room and were diagnosed as having AIS according to neuroimaging results. Data such as age, gender, time of symptom onset, medical history (stroke history), hypertension (HT), coronary artery disease (CAD), diabetes mellitus (DM), heart failure, atrial fibrillation, heart valve disease, liver or kidney failure, and medications used were recorded in the medical records and epicrisis of the patients. The NIHSS score of all patients was calculated, and those less than 5 were considered as having MIS (4).
In order to determine the etiology of stroke, brain-neck CT angiography, cranial magnetic resonance imaging (MRI), control cranial CT, electrocardiogram, echocardiogram, 24-hour rhythm holter, and digital cerebral angiography in necessary patients were performed in the patients.

From hospital records, the files of 659 patients followed up for 1 year with the diagnosis of AIS in our neurology clinic were scanned. Three hundred and thirty one patients with NIHSS score less than 5 were identified. In line with the exclusion and inclusion criteria of the study, 310 patients were included in the study. Thirteen patients were excluded from the study because they did not have regular follow-up at the Neurology Clinic of Bursa Uludag University for 3 months after stroke, and 8 patients were excluded from the study because of incomplete evaluation to elucidate the etiology of stroke. The stroke etiology of the patients was determined by the neurologist using the Trial of Org 10172 in acute stroke treatment (TOAST) stroke classification.

Presence of atherosclerosis in the cranial arteries of the patients was evaluated by the radiologist using the NASCET method. The anterior circulation was evaluated as the internal carotid artery (ICA) and its branches, while the posterior circulation was evaluated as the basilar artery and its branches of both vertebral arteries $(11,12)$.

The patients were treated in accordance with the stroke guidelines and appropriate medical agents were started. Revascularization was performed in necessary patients. Stroke recurrence and clinical outcomes of the patients who were followed up in the neurology stroke outpatient clinic at the $3^{\text {rd }}$ month after IS were determined. The clinical outcome of the patients was calculated using the modified Rankin scale (mRS) score. Those with mRS scores of 0,1 and 2 were evaluated as having good clinical outcome, and those with mRS scores of 3, 4, 5 and 6 as having poor clinical outcome. Patients with MIS were divided into 2 groups as those with and without RIS, and clinical, dermographic and radiological features of both groups were compared.

\section{Statistical Analysis}

Clinical, demographic and radiological data of patients with MIS were compared. The analyzes of the variables were made with the IBM SPSS Statistic 23 package program. For normally distributed continuous variables; number, mean and standard deviations were determined. Independent samples were analyzed by using t-test. Median value, $25^{\text {th }}$ and $75^{\text {th }}$ percentile values were used for the variables that were not normally distributed, and were evaluated with the Mann-Whitney $U$ test. Percentages were given for categorical variables and evaluated with the chi-square test. Statistically significant variables for RIS in patients with MIS were analyzed by using binary logistic regression.

\section{Results}

A total of 310 patients, 195 (63\%) males and 115 (37\%) females, with a diagnosis of MIS were included in this study. The mean age of women was $64.50 \pm 12.03$ years, while the mean age of men was $64.31 \pm 11.11$ years. There was no statistically significant difference in terms of the mean age of women and men $(\mathrm{p}=0.68)$. When the etiologies of IS were evaluated, $106(34 \%)$ patients had IS due to large artery atherosclerosis (LAA), 81 (26\%) patients due to cardioembolism, 80 (26\%) patients due to small vessel disease, and $9(3 \%)$ patients due to other causes. IS of unknown cause was 
present in $34(11 \%)$ patients. There were 207 (67\%) patients with anterior circulation stroke and $103(33 \%)$ patients with posterior circulation stroke. While the most common etiologic cause of anterior circulation stroke was LAA (42\%), the most common etiologic cause of posterior circulation stroke was small vessel disease $(45 \%)$. There was a statistically significant relationship between TOAST stroke classification and anterior and posterior circulation stroke $(\mathrm{p}=0.006)$.

Recurrence of IS was detected in $39(12 \%)$ patients in the first 3 months after stroke. Twelve (4\%) patients included in our study had poor clinical outcome and $298(96 \%)$ patients had good clinical outcomes. Carotid artery stenting was performed on the symptomatic ICA in 88 patients included in our study. During the study, there was no patient who underwent stenting to the asymptomatic ICA, vertebral artery and basilar artery.
When clinical, radiological and dermographic features were compared between patients with and without RIS, presence of CAD ( $p=0.001)$, atherosclerotic vascular disease vs other etiologies $(\mathrm{p}=0.046)$, anterior circulation stroke $(\mathrm{p}=0.02)$, craniocervical atherosclerotic stenosis $(\mathrm{p}=0.001)$, atherosclerotic stenosis in the anterior circulation $(\mathrm{p}<0.001)$, atherosclerotic stenosis in the symptomatic ICA $(\mathrm{p}<0.001)$, atherosclerotic stenosis in the asymptomatic ICA $(\mathrm{p}<0.001)$ and carotid artery stenting $(\mathrm{p}=0.003)$ were related with RIS. There were no differences between groups in terms of age $(p=0.32)$, gender $(p=0.19)$, DM $(p=0.25)$, HT $(p=0.27)$, smoking $(p=0.5)$, presence of atrial fibrillation $(p=0.64)$, LDL value $(\mathrm{p}=0.90)$, posterior circulation stroke $(\mathrm{p}=0.92)$, presence of atherosclerotic stenosis in the posterior circulation $(\mathrm{p}=0.13)$, symptomatic vertebral artery stenosis $(\mathrm{p}=0.43)$, asymptomatic vertebral artery stenosis $(\mathrm{p}=0.65)$, basilar artery atherosclerotic stenosis $(\mathrm{p}=0.5)$, and clinical outcome $(\mathrm{p}=0.66)$ (Table 1$)$.

Table 1. The comparison of clinical, radiological and demographic features of patients with minor ischemic stroke with and without recurrent ischemic stroke

\begin{tabular}{|c|c|c|c|}
\hline Age $^{*}$ mean $\pm \mathrm{SD}$ & $65.67 \pm 10.44$ & $64.20 \pm 11.60$ & 0.32 \\
\hline Gender** & $25(64 \%)$ & $170(63 \%)$ & 0.19 \\
\hline Male gender & $17(44 \%)$ & $99(37 \%)$ & - \\
\hline $\mathrm{DM}^{* * *}$ & $34(88 \%)$ & $207(76 \%)$ & 0.27 \\
\hline $\mathrm{HT}^{* *}$ & $16(41 \%)$ & $23(8 \%)$ & 0.001 \\
\hline $\mathrm{CAD}^{* *}$ & $19(49 \%)$ & $103(38 \%)$ & 0.5 \\
\hline Smoking & $8(20 \%)$ & $69(25 \%)$ & 0.64 \\
\hline Atrial fibrillation** & $130.60 \pm 46.91$ & $126.91 \pm 37.50$ & 0.90 \\
\hline TOAST stroke classification ${ }^{* *}$ & - & - & 0.046 \\
\hline Large vessel atherosclerosis & $21(54 \%)$ & $85(31 \%)$ & - \\
\hline Cardioembolic stroke & $8(20 \%)$ & $73(27 \%)$ & - \\
\hline Small vessel occlusion & $5(13 \%)$ & $75(28 \%)$ & - \\
\hline Stroke due to other causes & $2(5 \%)$ & $7(3 \%)$ & - \\
\hline Cryptogenic stroke & $3(8 \%)$ & $31(11 \%)$ & - \\
\hline Anterior circulation stroke & $33(87 \%)$ & $6(2 \%)$ & 0.02 \\
\hline Posterior circulation stroke & $15(38 \%)$ & $98(36 \%)$ & 0.92 \\
\hline Craniocervical atherosclerotic stenosis ${ }^{* * *}$ & $28(72 \%)$ & $11(4 \%)$ & 0.001 \\
\hline Atherosclerotic stenosis in the anterior circulation ${ }^{* *}$ & $13(33 \%)$ & $96(35 \%)$ & $<0.001$ \\
\hline $\begin{array}{l}\text { Atherosclerotic stenosis of the symptomatic internal } \\
\text { carotid artery** }\end{array}$ & $26(67 \%)$ & $78(29 \%)$ & $<0.001$ \\
\hline $\begin{array}{l}\text { Atherosclerotic stenosis of the asymptomatic internal } \\
\text { carotid artery** }\end{array}$ & $20(51 \%)$ & $55(20 \%)$ & $<0.001$ \\
\hline Atherosclerotic stenosis in the posterior circulation** & $10(26 \%)$ & $29(11 \%)$ & 0.13 \\
\hline $\begin{array}{l}\text { Atherosclerotic stenosis of the symptomatic vertebral } \\
\text { artery** }\end{array}$ & $5(13 \%)$ & $24(9 \%)$ & 0.43 \\
\hline $\begin{array}{l}\text { Atherosclerotic stenosis of the asymptomatic } \\
\text { vertebral artery** }\end{array}$ & $7(18 \%)$ & $21(8 \%)$ & 0.65 \\
\hline Atherosclerotic stenosis of the basilar artery** & $2(5 \%)$ & $8(3 \%)$ & 0.50 \\
\hline Carotid artery stenting procedure & $19(49 \%)$ & $69(25 \%)$ & 0.003 \\
\hline Clinical outcome (poor outcome) & $2(5 \%)$ & $10(37 \%)$ & 0.66 \\
\hline
\end{tabular}


Table 2. Evaluation of significant variables affecting minor ischemic stroke and stroke recurrence by using binary logistic regression

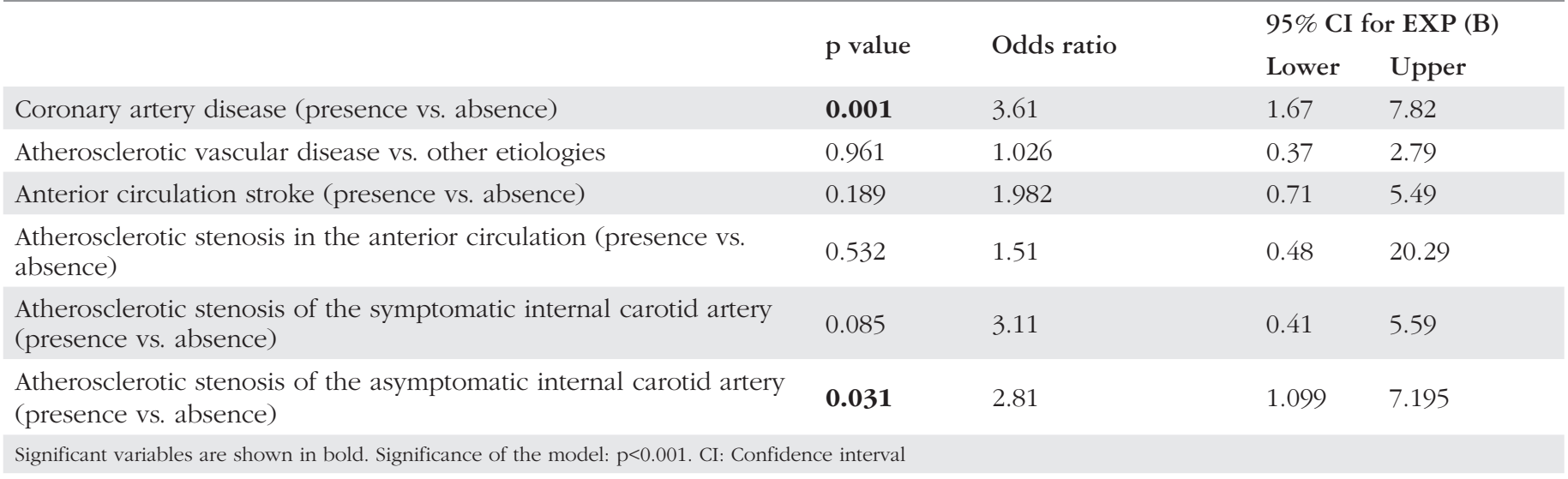

When significant variables were analyzed by using binary logistic regression in patients with MIS, the most significant variables were found to be CAD $(\mathrm{p}=0.001)$ and asymptomatic ICA stenosis $(\mathrm{p}=0.031)$ (Table 2$)$.

\section{Discussion}

The risk of RIS in the first 3 months in patients with MIS is $10-13 \%$. About $30 \%$ of patients with MIS have a poor clinical outcome (mRS score of 2-6) in the first 3 months. In addition, approximately one-third of patients admitted to the hospital due to MIS were not discharged home and cannot walk independently at discharge $(4,13)$. The triage of patients with MIS or transient ischemic attack (TIA) admitted to the emergency department is based on the stroke risk calculated based on age, blood pressure, clinical findings, duration of symptoms, and presence of DM (ABCD2). If the ABCD2 score is 4 or higher, it is recommended that patients with TIA or MIS be taken to emergency care for the first 24 hours. However, 22\% of patients with RIS have an ABCD2 score of less than 4 , and preventable causes of stroke such as symptomatic ICA stenosis and atrial fibrillation are not evaluated in the ABCD2 score (14). Many scores have been used to predict the risk of early stroke after TIA or MIS, including the ABCD2 score and the ABCD3-I score, which includes other neurovascular and cranial imaging findings $(15,16,17)$. Studies have shown that scoring supported by imaging is superior in predicting stroke recurrence in patients. The meta-analysis of studies evaluating more than 130,000 patients with MIS or TIA showed that those scoring systems lacked reliability in identifying patients with LAA as a provocateur of early stroke risk $(7,18,19,20)$. A consistent predictor of clinical outcome in patients with MIS is evidence of LAA on imaging, however, presence of LAA is also associated with long-term disability $(21,22)$.

According to binary logistic regression analysis in our study, one of the factors most associated with RIS in patients with MIS was atherosclerotic stenosis in the asymptomatic ICA. The reason for this may be the application of carotid artery stenting to the symptomatic ICA in the early post-stroke period in patients followed up in a comprehensive stroke center. Carotid stenting of the symptomatic ICA in patients with MIS in the early period protects the patient from RIS. However, atherosclerotic stenosis of the asymptomatic ICA is not uncommon in patients with
AIS. It occurs in $\leq 51 \%$ of patients. The reported rate of severe bilateral carotid stenosis and/or occlusion varies widely $(3.2 \%$ $39 \%)(23,24,25,26)$. In addition, the most reasonable timing for sequential carotid artery stenting in the presence of atherosclerotic stenosis in both ICAs has still not been determined (27). Although no criteria have been established to indicate the optimal timing of subsequent carotid artery stenting, a delay of at least 1 month is recommended. Because the application of stenting to the asymptomatic ICA in the same session in a patient with AIS may cause cerebral hyperperfusion syndrome (28). For this reason, there was no patient who underwent stenting of the asymptomatic ICA in our study.

One of the causes of RIS in patients with IS is atherosclerotic disease of the aortic arch (29). Atherosclerotic disease of the aortic arch is classified as cryptogenic stroke according to the TOAST stroke classification (30). However, the rate of RIS was low in patients with cryptogenic stroke in our patient group. In our study, atrial fibrillation was not detected as a variable related to RIS in patients with MIS. This may be due to the early anticoagulation in patients and anticoagulants in patients with atrial fibrillation may protect against RIS at a high rate $(31,32,33,34)$.

According to the binary logistic regression results in our study, CAD was one of the most significant variables associated with RIS. There is a well-documented risk of myocardial infarction in the first 3 months from the onset of stroke in patients who have had an IS $(35,36)$. In autopsy series of patients with IS or TIA, coronary artery plaques were found in up to $80 \%$ of patients and coronary artery stenosis with a rate of $40-50 \%$ were found in patients $(37,38)$. In other studies, it has been found that the increase in the severity and prevalence of coronary artery stenosis also increases the risk factor of craniocervical atherosclerotic stenosis, which is a risk factor of early RIS (39). In our study, small vessel disease was not evaluated as a significant variable associated with RIS in patients with MIS. In patients with small vessel disease, blood pressure-lowering therapy is very effective when combined with other risk factor managements and antiplatelet therapy (40).

\section{Conclusion}

In our study, the risk factors associated with RIS in patients with MIS were the presence of CAD and asymptomatic ICA stenosis. Atherosclerosis is a systemic disease and therefore craniocervical 
atherosclerotic stenosis may be multiple. Angiographic evidence has also revealed ethnic and racial differences in patients with AIS. For this reason, more precise information can be obtained with prospective studies to be conducted in our own population.

\section{Ethics}

Ethics Committee Approval: Approval for the study was obtained from the Clinical Research Ethics Committee of Bursa Uludag University Faculty of Medicine with the letter dated 03.03.2021 and numbered 2021-5/13.

Informed Consent: Retrospective study.

Peer-review: Externally peer-reviewed.

\section{Authorship Contributions}

Surgical and Medical Practices: Y.D., B.H., M.B., Concept: Y.D., B.H., M.B., Design: Y.D., Data Collection or Processing: Y.D., E.O.A., Analysis or Interpretation: Y.D., E.O.A., B.H., M.B., Literature Search: Y.D., Writing: Y.D.

Conflict of Interest: No conflict of interest was declared by the authors.

Financial Disclosure: The authors declared that this study received no financial support.

\section{References}

1. Oza R, Rundell K, Garcellano M. Recurrent ischemic stroke: strategies for prevention. Am Fam Physician 2017;96:436-440.

2. Wang $\mathrm{Y}$, Wang $\mathrm{Y}$, Zhao $\mathrm{X}$, et al. Clopidogrel with aspirin in acute minor stroke or transient ischemic attack. N Engl J Med 2013;369:11-19.

3. Daubail B, Durier J, Jacquin A, et al. Factors associated with early recurrence at the first evaluation of patients with transient ischemic attack. J Clin Neurosci 2014;21:1940-1944.

4. Fischer U, Baumgartner A, Arnold M, et al. What is a minor stroke? Stroke 2010;41:661-666.

5. Dhamoon MS, Moon YP, Paik MC, et al. Long-term functional recovery after first ischemic stroke: the Northern Manhattan Study. Stroke 2009;40:28052811.

6. Reeves M, Khoury J, Alwell K, et al. Distribution of national institutes of health stroke scale in the Cincinnati/Northern Kentucky stroke study. Stroke 2013;44:3211-3213.

7. Arsava EM, Kim GM, Oliveira-Filho J, et al. Prediction of early recurrence after acute ischemic stroke. JAMA Neurol 2016;73:396-401.

8. Kang DW, Yoo SH, Chun S, et al. Inflammatory and hemostatic biomarkers associated with early recurrent ischemic lesions in acute ischemic stroke. Stroke 2009;40:1653-1658.

9. Lee M, Wu YL, Ovbiagele B. Trends in incident and recurrent rates of first-ever ischemic stroke in Taiwan between 2000 and 2011. J Stroke 2016;18:60-65.

10. Bergström L, Irewall AL, Söderström L, et al. One-year incidence, time trends, and predictors of recurrent ischemic stroke in Sweden from 1998 to 2010: an observational study. Stroke 2017;48:2046-2051.

11. Kumral E, Topcuoglu MA, Onal MZ. Anterior circulation syndromes. Handb Clin Neurol 2009;93:485-536.

12. Easton DJ, Fauci AS, Isselbacher KJ. Cerebrovascular disease. In: Anonymous Harrison's Principle of Internal Medicine. Fauci AS, Longo D, Kasper DL, Wilson JD, Martin JB, eds. New York: McGraw Hill, 1998:2325-2348.

13. Khatri P, Conaway MR, Johnston KC; Acute Stroke Accurate Prediction Study (ASAP) Investigators. Ninety-day outcome rates of a prospective cohort of consecutive patients with mild ischemic stroke. Stroke 2012;43:560-562.

14. Amarenco P, Labreuche J, Lavallée PC, et al. Does ABCD2 score below 4 allow more time to evaluate patients with a transient ischemic attack? Stroke 2009;40:3091-3095.

15. Josephson SA, Sidney S, Pham TN, Bernstein AL, Johnston SC. Higher $\mathrm{ABCD} 2$ score predicts patients most likely to have true transient ischemic attack. Stroke 2008;39:3096-3098.
16. Purroy F, Jiménez-Caballero PE, Mauri-Capdevila G, et al. PROMAPA study: stroke project, cerebrovascular diseases study group, Spanish neurological society. Predictive value of brain and vascular imaging including intracranial vessels in transient ischaemic attack patients: external validation of the ABCD3-I score. Eur J Neurol 2013;20:1088-1093.

17. Kiyohara T, Kamouchi M, Kumai Y, et al. ABCD3 and ABCD3-I scores are superior to $\mathrm{ABCD} 2$ score in the prediction of short- and long-term risks of stroke after transient ischemic attack. Stroke 2014;45:418-425.

18. Wardlaw JM, Brazzelli M, Chappell FM, et al. ABCD2 score and secondary stroke prevention: meta-analysis and effect per 1,000 patients triaged. Neurology 2015;85:373-380.

19. Purroy F, Jiménez Caballero PE, Gorospe A, et al. Stroke Project of the Spanish cerebrovascular diseases study group. Prediction of early stroke recurrence in transient ischemic attack patients from the PROMAPA study: a comparison of prognostic risk scores. Cerebrovasc Dis 2012;33:182-189.

20. Purroy F, Montaner J, Molina CA, et al. Patterns and predictors of early risk of recurrence after transient ischemic attack with respect to etiologic subtypes. Stroke 2007;38:3225-3229.

21. Smith EE, Fonarow GC, Reeves MJ, et al. Outcomes in mild or rapidly improving stroke not treated with intravenous recombinant tissue-type plasminogen activator: findings from get with the guidelines-stroke. Stroke 2011;42:3110-3115.

22. Willey JZ, Stillman J, Rivolta JA, et al. Too good to treat? Outcomes in patients not receiving thrombolysis due to mild deficits or rapidly improving symptoms. Int J Stroke 2012;7:202-206.

23. Mathur A, Roubin GS, Iyer SS, et al. Predictors of stroke complicating carotid artery stenting. Circulation 1998;97:1239-1245.

24. Diehm N, Katzen BT, Iyer SS, et al. Staged bilateral carotid stenting, an effective strategy in high-risk patients - insights from a prospective multicenter trial. J Vasc Surg 2008;47:1227-1234.

25. Roubin GS, New G, Iyer SS, et al. Immediate and late clinical outcomes of carotid artery stenting in patients with symptomatic and asymptomatic carotid artery stenosis: a 5-year prospective analysis. Circulation 2001;103:532-537.

26. White CJ, Iyer SS, Hopkins LN, et al. Carotid stenting with distal protection in high surgical risk patients: the BEACH trial 30 day results. Catheter Cardiovasc Interv 2006;67:503-512.

27. Naylor AR. Delay may reduce procedural risk, but at what price to the patient? Eur J Vasc Endovasc Surg 2008;35:383-391.

28. Liu S, Jung JH, Kim SM, et al. Simultaneous bilateral carotid stenting in high-risk patients. AJNR Am J Neuroradiol 2010;31:1113-1117.

29. Fujimoto S, Yasaka M, Otsubo R, et al. Aortic arch atherosclerotic lesions and the recurrence of ischemic stroke. Stroke 2004;35:1426-1429.

30. Ay H. Etiologic classification in ischemic stroke. Turk J Neurol 2011;17:16.

31. Kaithoju S. Ischemic stroke: risk stratification, warfarin treatment and outcome measure. J Atr Fibrillation 2015;8:1144.

32. Patel MR, Mahaffey KW, Garg J, et al. Rivaroxaban versus warfarin in nonvalvular atrial fibrillation. N Engl J Med 2011;365:883-891.

33. Granger $\mathrm{CB}$, Alexander JH, McMurray JJ, et al. Apixaban versus warfarin in patients with atrial fibrillation. N Engl J Med 2011;365:981-992.

34. Connolly SJ, Ezekowitz MD, Yusuf S, et al. Dabigatran versus warfarin in patients with atrial fibrillation. N Engl J Med 2009;361:1139-1151.

35. Dhamoon MS, Sciacca RR, Rundek T, Sacco RL, Elkind MS. Recurrent stroke and cardiac risks after first ischemic stroke: the Northern Manhattan Study. Neurology 2006;66:641-646.

36. Prosser J, MacGregor L, Lees KR, et al. Predictors of early cardiac morbidity and mortality after ischemic stroke. Stroke 2007;38:2295-2302.

37. Amarenco P, Lavallée PC, Labreuche J, et al. Prevalence of coronary atherosclerosis in patients with cerebral infarction. Stroke 2011;42:22-29.

38. Calvet D, Touzé E, Varenne O, et al. Prevalence of asymptomatic coronary artery disease in ischemic stroke patients: the PRECORIS study. Circulation 2010;121:1623-1629.

39. Amarenco P, Lavallee PC, Labreuche J, et al. Coronary artery disease and risk of major vascular events after cerebral infarction. Stroke 2013;44:15051512.

40. Karaoğlan M. One-year risk of stroke after transient ischemic attack or minor stroke. Turk J Neurol 2017;23:144-145. 